УДК 342.922

DOI https://doi.org/10.32844/2618-1258.2019.3-1.28

КОМІРЧИЙ П.О.

\title{
СУТНІСТЬ ФОРМ ДІЯЛЬНОСТІ ОРГАНІВ ПУБЛІЧНОЇ СЛУЖБИ У ПРАВООХОРОННІЙ СФЕРІ УКРАЇНИ
}

Метою наукової статті є окреслення сутнісного змісту форм діяльності органів публічної служби у правоохоронній сфері України. У статті з'ясовуються основні методико-теоретичні проблеми узагальнення форм діяльності органів публічної служби у правоохоронній сфері держави, а також виявляються методологічні можливості щодо вирішення цих проблем. Особлива увага автора приділяється критичному аналізу наявних науково-теоретичних підходів учених до розуміння понять «форма», «форма діяльності» та «форма діяльності органів публічної служби», на основі чого формулюється визначення поняття «форми діяльності органів публічної служби у правоохоронній сфері України», окреслюється його сутнісний зміст. У висновках до статті узагальнюються основні результати проведеного дослідження. Наголошено, що форма діяльності державних органів і публічних службовців у наукових працях ученими та дослідниками загалом окреслюється через різні поняття. Визначено, що форми діяльності органів публічної служби у правоохоронній сфері нашої держави - це зовнішнє практичне вираження дій і рішень публічних службовців органів публічної служби у відповідній сфері, що ними вчиняються (приймаються) на підставі, в межах повноважень та у спосіб, що передбачені чинним законодавством України, з метою забезпечення та здійснення покладених на них чинним законодавством завдань у правоохоронній сфері держави. Зроблено висновок, що в узагальненому вигляді форми діяльності органів публічної служби у правоохоронній сфері можуть теоретично осмислюватись як практичне вираження компетентної реалізації відповідними органами групи покладених на них законодавцем завдань у сфері правоохорони. При цьому з метою уніфікації знань про вказані форми діяльності подальше їх дослідження доцільно розглядати як певну узгоджену структуру, що охоплює такі форми діяльності: правові форми діяльності (нормотворчу, правозастосовну, установчу, контрольно-наглядову, виконавчу форми діяльності); неправові форми діяльності (організаційні та матеріально-технічні форми діяльності).

Ключові слова: адміністративно-правовий статус, органи публічної служби, правоохоронна сфера, публічна служба, форма діяльності.

The purpose of this scientific article is to outline the essential content of the forms of activity of public service bodies in the law enforcement sphere of Ukraine. The article determines core methodic and theoretical problems of generalizing the activity forms of public service bodies at the law enforcement area of the state and identifies methodological capacities to solve these problems. The author pays a particular attention to a critical analysis of the existing scientific and applied approaches to understanding the concepts of "form", "activity form" and "activity form of public service bodies". On this basis the definition of the "activity forms of public service bodies at the law enforcement area of Ukraine" concept is formulated, and its essential content is outlined. To conclude the article, the main results of the research are generalized. It is emphasized that the form of activity of state bodies and public officials in scientific works of scientists and researchers is generally defined at the expense of different concepts. It is determined that the forms of activity of public service bodies in the law enforcement sphere of our state is an external practical expression of actions and decisions of public officials of

( ) КОМІРЧИЙ П.О. - кандидат юридичних наук, доцент, докторант кафедри публічного управління та адміністрування (Національна академія внутрішніх справ) 
public service bodies in the respective sphere, which they (are) committed on the basis, within the powers and in the manner provided by the current legislation. Ukraine, in order to ensure and fulfill the tasks assigned to them by the current legislation in the law enforcement sphere of the state. It is concluded that in the generalized form of activity of public service bodies in the law enforcement sphere can be theoretically considered as a practical expression of competent implementation by the respective bodies of the group of tasks assigned to them by the legislator in the field of law enforcement. At the same time, in order to unify knowledge about these forms of activity, their further research should be considered as a certain coherent structure, covering the following forms of activity: legal forms of activity (rulemaking, law enforcement, constituent, control and executive form of activity); non-legal forms of activity (organizational and logistical forms of activity).

Key words: activity form, administrative and legal status, law enforcement area, public service bodies, public service.

Вступ. Загальновідомо, що публічна влада в будь-якій державі не спроможна реалізовуватись сама по собі. 3 огляду на це публічна влада повсюдно та повсякчас об'єктивується у складному комплексі конкретних дій різного роду, що «виражають її зміст і спрямованість», здійснених компетентними суб' єктами цієї влади, тобто відповідними державними органами. Серед цих органів є також і виконавчі органи публічної влади, що «повсякденно та багатоманітним чином» реалізують державну владу [1, с. 196]. При цьому вказана діяльність, звісно, не може здійснюватися безсистемно, хаотично. Саме тому законодавцем передбачається, що органи публічної служби функціонують у межах певних форм діяльності, застосовуючи певні методи діяльності. Утім, у цьому контексті слід мати на увазі, що відповідні форми та методи діяльності, будучи зумовленими метою і завданнями відповідних органів, застосовними в одній сфері діяльності держави, не можуть застосовуватись (повністю у тому ж самому вигляді) в іншій сфері діяльності держави.

Особливим чином вказане питання стосується діяльності органів публічної служби у правоохоронній сфері, визначеність, узгодженість і виправданість характеру форм і методів діяльності яких прямо позначаються на рівні забезпечення прав людини в державі, показниках верховенства права та можливостях віднесення держави до групи сучасних правових держав.

Аналіз наукової літератури та не вирішені питання. Формам діяльності загалом і формам діяльності органів публічної служби зокрема вже тією чи іншою мірою приділяється увага українських учених і дослідників (це, зокрема, О.М. Алікова, О.О. Бандурка, М.П. Гурковський, С.С. Ссімов, I.О. Клочко, Т.М. Кравцова, О.М. Рєзнік та інші вчені). Водночас слід зауважити, що по сьогодні в теорії адміністративного права України ще не було комплексно досліджено питання форм діяльності органів публічної служби у правоохоронній сфері нашої держави. Закономірним чином вказана проблема потребує виправлення шляхом здійснення комплексної наукової розвідки форм діяльності відповідних органів публічної служби.

Постановка завдання. Метою наукової статті є окреслення сутнісного змісту форм діяльності органів публічної служби у правоохоронній сфері України. Для досягнення поставленої мети необхідно вирішити такі завдання: 1) виявити методико-теоретичні проблеми узагальнення форм діяльності органів публічної служби у правоохоронній сфері держави, а також з'ясувати можливості щодо вирішення цих проблем; 2) критично проаналізувати наявні науково-теоретичні підходи вчених до розуміння понять «форма», «форма діяльності» та «форма діяльності органів публічної служби», на основі чого сформулювати визначення поняття «форми діяльності органів публічної служби у правоохоронній сфері України»; 3) окреслити сутнісний зміст основних форм діяльності органів публічної служби в досліджуваній сфері.

Результати дослідження. Спершу слід зауважити, що зміст, види та форми службово-трудової діяльності публічних службовців у системі органів виконавчої влади загалом $є$ досить різноманітними. Наприклад, В.І. Матирко ще у 1997 році звертав увагу на те, що публічні службовці залежно від різних груп посад виконують частину завдань публічного управління (вчений указує на те, що «... вони займаються досить диференційованими видами діяльності в галузі державного управління», хоча, на нашу думку, не доцільно ігнорувати й того, що публічні службовці не обмежуються у своїй діяльності лише управлінською діяльністю, зокрема, й у частині правових форм діяльності). Окрім того, як зазначає В.І. Матирко, «... навіть професійна кваліфікація цих 
посадових осіб багато в чому визначається місцем державного службовця в системі сфери управління та конкретним посадовим рівнем кожного окремого працівника». При цьому окреслене різноманіття ознак, на думку вченого, пояснює «труднощі та навіть марність» усіх попередніх спроб учених викласти універсальний опис функціональних обов'язків публічних службовців [2, с. 84].

В окресленому контексті необхідно звернути увагу на те, що зазначена проблема не повною мірою може бути полегшеною шляхом звуження дослідження до аналізу форм діяльності органів публічної служби певної сфери діяльності держави, в якій, як можна було би припустити, державні органи спрямовані на досягнення лише певної спільної для них мети. Зокрема, необхідно мати на увазі, що форми діяльності органів публічної служби у сфері правоохорони України відображають загальні форми діяльності цих органів як таких, відповідаючи таким чином меті, завданням і функціям цих органів публічної служби, що сукупно визначають відповідну діяльність. Утім, вказане не полегшує очевидну методико-теоретичну проблему узагальнення цих форм діяльності (особливо - їхніх складників). Відтак узагальнююче дослідження форм діяльності відповідних органів публічної служби, на нашу думку, повинно поглиблюватись до тієї міри, за якої вказані органи можуть бути осмислені як такі, що виконують спільну діяльність.

Звернемо увагу на те, що до окресленої проблеми вже звертались, зокрема, українські вчені-адміністративісти М.П. Гурковський і С.С. Єсімов, що розглядали можливості узагальнення форм діяльності поліції, котрі застосовуються в процесі забезпечення прав і свобод людини та громадянина. На думку вчених, «... виправданим $є$ виокремлення форм діяльності поліції в цій сфері, які б, по-перше, відповідали всім формальним ознакам цього поняття, а по-друге, розкривали сутність змісту будь-якого напряму діяльності» [3, с. 174]. 3 вказаним висновком, що цілком узгоджується 3 нашою позицією з приводу вирішення зазначеної проблеми, ми погоджуємось повною мірою.

Водночас дослідження форм діяльності органів публічної служби у правоохоронній сфері нашої держави сьогодні не може бути здійснене в достатньою мірою без з'ясування сутності цих форм діяльності, підходів до їх класифікації, виявлення та вирішення цих проблем. У цьому контексті щонайперше слід звернути увагу на те, що форма діяльності державних органів і публічних службовців у наукових працях ученими та дослідниками загалом окреслюється через різні поняття. Зокрема, вченими використовуються такі поняття: «форма діяльності органів публічної адміністрації», «форма реалізації державної виконавчої влади», «форма управління», «адміністративно-правова форма управління (діяльності)», «форма державного управління», «форма управлінської (виконавчої) діяльності» і т. д. Наприклад, українська вчена Т.М. Кравцова, досліджуючи форми управлінської діяльності, вказує на те, що вони відображені в діяльності державного апарату, яку вона фактично зводить до «регуляторної діяльності». При цьому, на думку вченої, наприклад, органи державної влади у сфері підприємництва здійснюють регуляторну діяльність у таких формах: 1) прийняття регуляторного акта; 2) реєстрація суб'єктів підприємництва; 3) ліцензування та патентування підприємницької діяльності; 3) сертифікація та стандартизація продукції (послуг); 4) видача дозволу на заняття підприємницької діяльності; 5) здійснення державного контролю за підприємницькою діяльністю тощо [4, с. 88]. Зі свого боку О.М. Алікова виокремлює виконавчу, розпорядчу та організаційну (чи організаційно-правову) форми діяльності державних органів. На думку української вченої, виконавча і розпорядницька діяльність це своєрідна форма здійснення управління, а організаційна діяльність - це форма здійснення управління, сутність якої наповнює управління специфічним змістом (зокрема, включає в себе сполучення таких елементів, як координація, регулювання і контроль). У цьому контексті вчена звертає увагу на те, що «виділення організуючого характеру управління» показує, чим займаються відповідні органи управління [5, с. 212-213]. Отже, О.М. Алікова розглядає управління як форму діяльності, що складається з різних форм здійснення діяльності - виконавчої, розпорядчої та організаційної.

Водночас I.О. Клочко вважає, що формами діяльності, зокрема, органів прокуратури щодо протидії корупції є такі форми діяльності: 1) координаційна форма діяльності як зовнішнє відображенням системи дій, спрямованих на об'єднання зусиль різних правоохоронних органів та інших громадських і державних інститутів у сфері протидії та запобігання корупції, узгодження дій цих інститутів і розмежування їхніх повноважень; 2) організаційно-правова форма діяльності, що виражає систему дій, які спрямовані на створення організаційних умов належного функціонування відповідних структурних підрозділів і прокурорів, що спеціалізуються на провадженні антикорупційних дій; 3) адміністративно-наглядова та контрольна форма діяльності як система дій, спрямованих на перевірку законності провадження діяльності в сфері протидії корупції; 
4) юрисдикційна форма діяльності як форма діяльності органів прокуратури, що пов'язана з провадженням у справах про корупційні адміністративні правопорушення; 5) аналітично-облікова форма діяльності, яка характеризується тим, що іiї основу становлять дії, спрямовані на узагальнення, аналіз, систематизацію, оприлюднення інформації про рівень корупції в державі, вжиті заходи щодо подолання корупції в Україні або в іiї окремому регіоні [6, с. 4].

Отже, можемо констатувати суттєву заплутаність підходів до концептуалізації теорії форм діяльності органів публічної служби, що, на нашу думку, виявляється в такому: 1) невизначеність поняття «форма діяльності» та сутнісного змісту форм діяльності органів публічної служби (як наслідок, види форм діяльності досить часто ототожнюються з формами діяльності); 2) наявність множини термінів, якими окреслюються відповідні форми діяльності, що використовуються як синоніми, хоча вони не завжди ними $€$ (тобто як такі).

На вказані проблеми вже тією чи іншою мірою зверталась увага українських учених-адміністративістів. Зокрема, О.О. Бандурка, аналізуючи наявність у теоретичних працях учених низки термінів, якими позначаються форми діяльності органів публічної служби, доходить думки, що деякі із цих термінів у жодному разі не можна вживати як синоніми. У цьому сенсі пропонується розмежовувати, наприклад, «форму управлінської діяльності», «форму державного управління», з одного боку, та «форму виконавчої діяльності», «форму реалізації виконавчої влади» - 3 іншого, «оскільки вони, відповідно, належать до державного управління та виконавчої влади, які не $\epsilon$ тотожними». Відтак такі терміни, як «форма управлінської діяльності», «форма державного управління», на думку О.О. Бандурки, є більш широкими, загальними щодо категорій «форма виконавчої діяльності», «форма реалізації виконавчої влади» [7, с. 231].

Вирішуючи поставлені в межах наукової розвідки завдання, спершу зазначимо, що слово «форма» у тлумачних словниках української мови розуміється так: 1) обриси, контури, зовнішні межі предмета, що визначають його зовнішній вигляд; 2) пристрій, шаблон, за допомогою якого чому-небудь надають певних обрисів, якогось вигляду; 3) тип, будова, спосіб організації чого-небудь; зовнішній вияв якого-небудь явища, пов'язаний з його сутністю, змістом; 4) спосіб існування змісту, внутрішня структура змісту, організація і зовнішне вираження; 5) видимість або зовнішній бік чого-небудь, що не відображає суті справи [8, с. 1543]. Закономірним чином у наукових дослідженнях і розвідках ученими окреслюються різні аспекти поняття «форми». Наприклад, М.М. Северін уважає, що форма - це суто філософська категорія, яка виражає собою «впорядкованість змісту, спосіб його здійснення», а також «конкретну, цю конфігурацію, взаємне розташування, елементів, що складають зміст, і спосіб, визначений порядок відносин і зв'язків між ними» [9, с. 215]. Л.С. Федорняк указує на те, що форма - це «зовнішнє вираження суті, порядку організації та структури» [10, с. 253]. Також вказане поняття розглядалось в юридичному аспекті. Зокрема, О.В. Петров уважає, що «форма» в юридичному контексті - це «спосіб зовнішнього подання істотного змісту явища», а тому має аналізуватись саме «в аспекті закономірних зв'язків із сутністю і змістом права» [11, с. 229].

Отже, як зазначає український юрист-адміністративіст О.М. Рєзнік, за допомогою форми визначається зовнішнє вираження змісту певних дій, феноменів. Водночас під час використання цього слова може йти мова «про певну умову, за існування якої таке явище набуває потрібного вигляду, формується спосіб його існування та функціонування тощо». Однак, як зазначає науковець, цей підхід до розуміння поняття «форма» є загальним і таким, що не дає змоги «зрозуміти специфіку саме правової діяльності» [12, с. 270]. Вказане може бути вирішене шляхом конкретизації поняття «форма», а саме - вказівкою на те, щодо чого воно використовується. В контексті питання, яке нами досліджується, важливою є саме «форма діяльності».

При цьому під «формою діяльності» вчені розуміють «... те, з чого діяльність починається, і те, що вона виробляс, і все це одночасно» [13, с. 18], а в адміністративно-правовому сенсі - «зовнішнє практичне вираження державно-управлінської діяльності» [14, с. 369]. Зокрема, на думку українського науковця О.М. Рєзніка, адміністративно-правові форми діяльності правоохоронних органів України як суб'єктів забезпечення фінансово-економічної безпеки держави є зовнішньо вираженими діями чи рішенням співробітників правоохоронних органів України, які вчиняються чи приймаються ними у межах національного законодавства з метою сприяння ефективному виконанню покладених на них чинним законом завдань щодо забезпечення фінансово-економічної безпеки держави [12, с. 274]. Тобто можемо дійти думки, що форми діяльності органів публічної служби у правоохоронній сфері нашої держави - це зовнішне практичне вираження дій і рішень публічних службовців органів публічної служби у відповідній сфері, що ними вчиняються (приймаються) на підставі, в межах повноважень та у спосіб, що передбачені чинним законодавством 
України, з метою забезпечення та здійснення покладених на них чинним законодавством завдань у правоохоронній сфері держави.

Висновки. Сьогодні у вітчизняній і зарубіжній теорії адміністративного права ще залишається невирішеною низка проблем щодо узагальненого розуміння форм діяльності органів публічної служби загалом. При цьому формам діяльності органів публічної служби у правоохоронній сфері вченими взагалі не приділяється належна увага. Водночас узагальнююче розуміння відповідних форм діяльності органів публічної служби у правоохоронній сфері нашої держави суттєво ускладняється тим, що, попри наявність у відповідних органів спільних рис діяльності, в правоохоронній сфері нашої держави вони також виконують спеціальну діяльність у межах комплексу особливих форм діяльності.

Утім, в узагальненому вигляді форми діяльності органів публічної служби у правоохоронній сфері можуть теоретично осмислюватись як практичне вираження компетентної реалізації відповідними органами групи покладених на них законодавцем завдань у сфері правоохорони. При цьому з метою уніфікації знань про вказані форми діяльності подальше їх дослідження доцільно розглядати як певну узгоджену структуру, що охоплює такі форми діяльності: правові форми діяльності (нормотворчу, правозастосовну, установчу, контрольно-наглядову, виконавчу форми діяльності); неправові форми діяльності (організаційні та матеріально-технічні форми діяльності).

\section{Список використаних джерел:}

1. Алехин А.П., Кармолицкий А.А., Козлов Ю.М. Административное право Российской Федерации : учебник. Москва : ИКД «Зерцало-М», 2003. 608 с.

2. Матирко В.И. Формирование кадрового потенщиала федеральных органов исполнительной власти : дисс. ... Д-ра экон. наук : 08.00.05. Москва, 1997358 с.

3. Гурковський М.П., Єсімов С.С. Основні форми та методи діяльності поліції у сфері забезпечення конституційних прав і свобод людини та громадянина України. Науковий вісник Львівського державного університету внутрішніх справ. 2016. № 4. С. 171-186.

4. Кравцова Т.М. Правові форми державного регулювання у сфері підприємницької діяльності. Актуальні проблеми держави і права. 2003. Вип. 19. С. 87-89.

5. Алікова О.М. Організаційно-правові форми діяльності державних органів у сфері фізичної культури і спорту. Актуальні проблеми держави і права. 2005. Вип. 25. С. 210-214.

6. Клочко I.О. Органи прокуратури України в системі суб'єктів протидії корупції: адміністративно-правовий аспект : дис. .... канд. юрид. наук : 12.00.07. Суми, 2018. 227 с.

7. Бандурка О.О. Сутність та види форм управлінської діяльності в Державній податковій службі України. Вісник Харківського наџіонального університету внутрішніх справ. 2005. № 30. C. $230-236$.

8. Великий тлумачний словник сучасної української мови (з додатками і доповненнями)/ уклад. і голов. ред. В.Т. Бусел. Київ; Ірпінь : Вид-во «Перун», 2005. 1728 с.

9. Северин Н.Н. Педагогическая оценка форм управления процессом профессиональной подготовки сотрудников ГПС МЧС России. Вестник БГТУ им. В.Г. Шухова. 2012. № 2. C. 215-218.

10. Федорняк Л.С. Формування персоналу сільськогосподарського підприємства. Актуальні проблеми розвитку економіки регіону. 2008. № 4. С. 253-258.

11. Петров А.В. Форма права и ее разновидности. Вестник Нижегородского университета им. Н.И. Лобачевского. 2012. № 6-1. С. 227-232.

12. Рєзнік О.М. Адміністративно-правові засади діяльності правоохоронних органів із забезпечення фінансово-економічної безпеки України : дис. ... д-ра юрид. наук : 12.00.07. Суми, 2019. 509 c.

13. Лебедев С.П. Проблема платоновского учения о началах. Известия Российского государственного педагогического университета им. А.И. Гериена. 2007. Т. 9. № 46. С. 7-18. $554 \mathrm{c}$.

14. Козлов Ю.М. Административное право : учебник. Москва : Изд-во «Юристъ», 2005. 